Original article

\title{
Assessment of air pollution by small-sized suspended particulate matter in urbanized territories with various technogenic load (on the example of Vladivostok, Russia)
}

\author{
Lyudmila S. Barskova, Tatyana I. Vitkina, Tatyana A. Gvozdenko, Lyudmila V. Veremchuk, Kirill S. Golokhvast
}

Institute of Medical Climatology and Rehabilitative Treatment, Vladivostok, Russia

Received 02 April 2018, Revised 12 April 2019, Accepted 30 April 2019

(C) 2018, Barskova L.S., Vitkina T.I., Gvozdenko T.A., Veremchuk L.V., Golokhvast K.S.

(C) 2018, Russian Open Medical Journal

Abstract: The aim of the study was to estimate the pollution of the atmospheric surface layer by suspended particulate matter (SPM) in two districts of Vladivostok with different levels of technogenic load.

Material and Methods - The air samples were taken in the "breathing zone" by an electric aspirator simultaneously to the liquid absorbing medium and on the filter, laser granulometry was used to assess the dispersion, and the mass concentration of the SPM fractions was calculated.

Results - Ultrafine particles were detected in the air in the area with a high man-made load. Air levels of particles with an aerodynamic diameter of $0.1-1 \mu \mathrm{m}, 1-2.5 \mu \mathrm{m}$ (respirable fraction) and 2.5-10 $\mu \mathrm{m}$ (tracheobronchial fraction) were 5, 2.7 and 3.3 times higher, respectively, in the area with a high man-made load in comparison with the area with insignificant technogenic load.

Conclusion - Particles with an aerodynamic diameter less than $10 \mu \mathrm{m}$, which have the most pathogenic effect, prevail in the air in the urbanized area with a high technogenic load. The predominance of SPM fractions with an aerodynamic diameter more than $10 \mu \mathrm{m}$ is a characteristic feature of air pollution in the territory with a low man-made load.

Keywords: suspended particulate matter, atmospheric surface layer, human health.

Cite as Barskova LS, Vitkina TI, Gvozdenko TA, Veremchuk LV, Golokhvast KS. Assessment of air pollution by small-sized suspended particulate matter in urbanized territories with various technogenic load (on the example of Vladivostok, Russia). Russian Open Medical Journal 2019; 8: e0304.

Correspondence to Lyudmila S. Barskova. Address: 73g, Russkaya str., Vladivostok, 690000, Russia. E-mail: pretty_people_2016@mail.ru.

\section{Introduction}

Air pollution by suspended particulate matter (SPM) is a major global problem. Small-sized particles may be transported long distances in the atmosphere. Thus these particles contribute to air pollution in areas located far from the source of pollution due to their physical characteristics [1-3].

The adverse effect of SPM on the human body mainly depends on their sizes and concentration in the air [4-6]. The SPM classification for hygienic assessment of dispersity and health effects is based on the ability of particles with a certain range of aerodynamic diameter to penetrate various parts of the human respiratory tract. Amongst them, the tracheobronchial and respirable fractions are the most important research objects. The tracheobronchial fraction is composed of respirable particles less than $10 \mu \mathrm{m}$ in an aerodynamic diameter (PM10) that enter the larynx, but do not penetrate into the lower respiratory tract. The respirable fraction includes particles less than $2.5 \mu \mathrm{m}$ in an aerodynamic diameter (PM2.5) [7]. PM2.5 are the most pathogenic particles, as they are able to deposit in the bronchioles, alveoli and pulmonary capillaries, as well as penetrate into the systemic circulation and in this way to enter the organs and directly affect the cells of various tissues [8]. According to modern concepts, ultrafine particles (UFP, particles less than $0.1 \mu \mathrm{m}$ in an aerodynamic diameter (PMO.1)) are able to pass through cell membranes. The introduction of UFP into a cell leads to disruption of its functioning and energy metabolism. The impossibility of the rapid elimination of micro-sized SPM leads to their chronic accumulation in organs and tissues, which result in long-term negative effect [9]. Adverse climatic factors and meteorological conditions can aggravate the effect of pollution particles [10].

Among the key air pollutants, PM2.5 has recently been recognized as one of the leading causes of death and disability worldwide. It is shown that an increase in level of PM2.5 in the air by $10 \mu \mathrm{g} / \mathrm{m}^{3}$ elevates the risk of death from cardiopulmonary diseases by about $6 \%$ and from lung cancer by $8 \%$ [11]. However, negative impact of SPM concentration not exceeding the levels of air quality standards on the respiratory tract in healthy subjects and weather sensitive people of all ages has also been reported [12, 13]. The elderly people, children and patients with cardiovascular and respiratory diseases are particularly vulnerable to the adverse effects of air microparticles [14-17].

To assess the influence of suspended particles on the human body, it is reasonable to study the particle size distribution of atmospheric suspensions for near-surface fractions that have a 
direct effect on the respiratory tract. Analyzing the modern scientific literature, the authors have not found studies focused on the pollution of atmospheric surface layer by micro-sized SPM and also taking into account the pathophysiological ranges of particle size distribution. An author's method of the collection of air samples into the liquid absorbing medium to determine the fractional composition of suspended particles has been developed in our Institute [18]. The method makes it possible to assess the size distribution of SPM in atmospheric surface layer in different year seasons. It is important to note that the sampling is done in the "breathing zone", which directly affects the human respiratory system.

The aim of the study was to estimate the pollution of the atmospheric surface layer by SPM in two districts of Vladivostok with different levels of technogenic load.

\section{Material and Methods}

The assessment of air pollution was carried out using data for the period 2013-2016. We collected and analyzed 68 air samples in the area with a low (30 samples) and a high (38 samples) technogenic load (Figure 1). All samples in these areas were taken from the same locations.

Russkiy Island (an administrative district of Vladivostok) was chosen as a relatively favorable zone with a low technogenic load. Russkiy Island is characterized by the absence of factories and large enterprises, and low density of residential building. The main sources of air pollution in the area are dirt roads with a high degree of dustiness and low traffic intensity (up to 60 cars/hour). Additional pollution sources during heating season (the last decade of October - the first decade of May) are stove and boiler heating systems in private residences. The physical and geographical features of this district are mainly determined by the presence of vast marine area (Novik Bay) and extensive forest area.

Vtoraya Rechka district (the mainland part of Vladivostok) was chosen as an unfavorable zone with a high technogenic load. This district is characterized by a high density of residential building. Air pollution in this area is associated with the presence of the waste incineration plant, the "Severnaya" district heating plant and the asphalt road with high traffic $(2,400-3,000$ cars/hour). Road transport and the waste incineration plant (located $500 \mathrm{~m}$ from the sampling site) contribute significantly to air pollution all year round, whereas the "Severnaya" plant doesn't work during nonheating season (May - October).

The samples were collected at a height of $1.5 \mathrm{~m}$ above the ground in order to determine the concentration of small-sized SPM in the atmospheric surface layer. The sampling site was placed in a fixed location. Air samples were collected using an PU$4 \mathrm{E}$ electric aspirator (Khimko, Russia) into a liquid absorbing medium (highly purified water) using a high-speed Richter's absorber at the rate of $10 \mathrm{l} / \mathrm{min}$. Richter's absorber No.1 contained a liquid medium for collecting SPM. Richter's absorber No.2 (empty) was located between the absorber and the inlet fitting of the corresponding channel and used to prevent ingress of the liquid absorber into the aspirator. At the same time, the sample was collected on the filter (AFA-VP-20) at a rate of $35 \mathrm{l} / \mathrm{min}$. The total mass of SPM and their concentration per unit volume were calculated.

The averaged data of 6 consecutive sampling cycles of 30 minutes (the time of one cycle corresponds to the sampling time required for calculating maximum allowable concentration (MAC)) with an interval between cycles of 5-10 minutes were considered as 1 air sample. The meteorological parameters (wind speed, wind direction, air temperature, atmospheric pressure, weather conditions and the state of underlying soil surface) were recorded at the beginning of each cycle.

The particle size analysis of SPM was conducted by laser granulometry (Analysette 22 NanoTech laser analyzer, Fitsch, Germany). The data were expressed in mass fractions. Weighing of the filters was carried out using electronic scales (Shimadzu, Japan). The total mass concentration of suspended particles per unit of air volume $\left(\mathrm{mg} / \mathrm{m}^{3}\right)$ was calculated, as well as the mass concentration of fractions $\left(\mu \mathrm{g} / \mathrm{m}^{3}\right)$ in each sample.

Statistical processing of the data was carried out using the Statistica 8.0 software. The results of non-parametric descriptive statistical analyses are presented as medians with low and upper quartiles - Me (LQ, UQ). The Mann-Whitney U-test was used to compare the obtained data. The significance threshold for statistical hypothesis testing was 0.05 .

\section{Results}

The mass concentrations of SPM in the atmospheric surface layer in two districts of Vladivostok with different levels of anthropogenic load were determined to assess air pollution. The following particle size ranges were detected: $0-0.1 \mu \mathrm{m}, 0.1-1 \mu \mathrm{m}$, 1-2.5 $\mu \mathrm{m}, 2.5-10 \mu \mathrm{m}, 10-100 \mu \mathrm{m}, 100-2000 \mu \mathrm{m}$ (Figure 2).

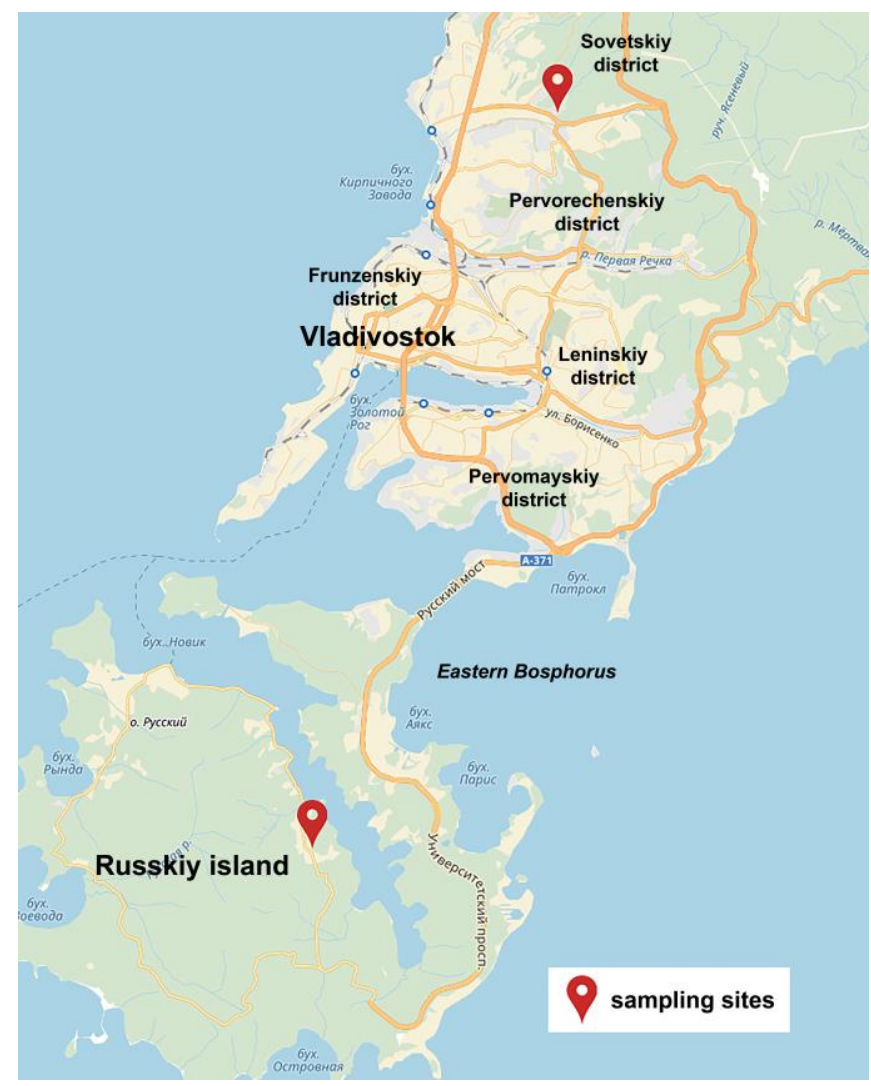

Figure 1. Location of the sampling sites of atmospheric surface layer in two districts of Vladivostok with different levels of man-made pollution. 


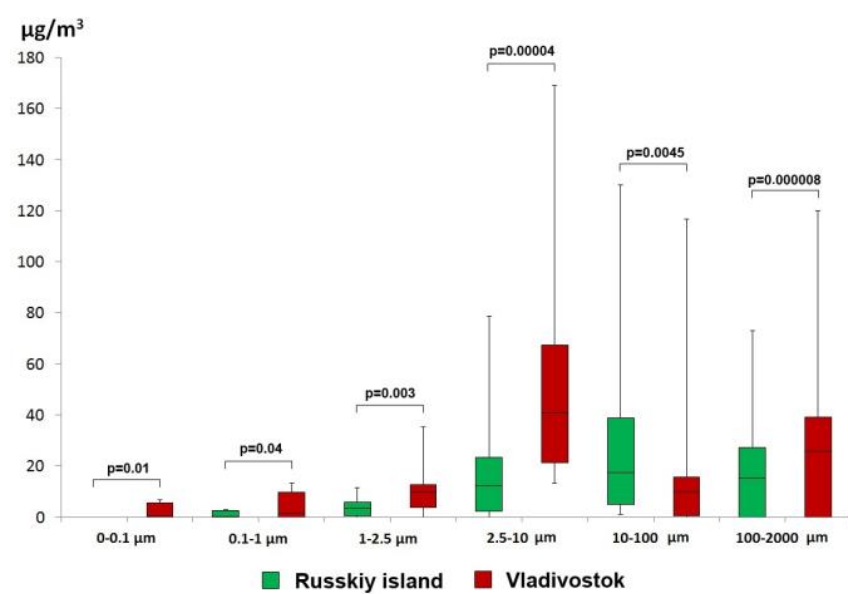

Figure 2. Concentration of suspended particulate matter (SPM) of different dispersity of the atmospheric surface layer in two districts of Vladivostok with different levels of technogenic load, $\mu / \mathrm{m}^{3}$. Data presented as $\mathrm{Me}(\mathrm{LQ}, \mathrm{UQ})$ with minimum and maximum.

Air concentration of UFP $(0-0.1 \mu \mathrm{m})$ in the area with significant man-made load (Vladivostok) was $0.6(0,5.5) \mu \mathrm{g} / \mathrm{m}^{3}$. UFP have not been detected $(p=0.01)$ in the air in the area with little technogenic load (Russkiy Island).

The particles with an aerodynamic diameter of 0.1-1 $\mu \mathrm{m}$ have the most significant differences in air concentration. SPM concentration in Vladivostok was 5 times higher $(1.5(0,6.7)$ $\left.\mu \mathrm{g} / \mathrm{m}^{3}\right)$ than in the area with a low technogenic load $(0.3(0,2.5)$ $\left.\mu \mathrm{g} / \mathrm{m}^{3}\right)(\mathrm{p}=0.04)$.

Air concentration of small-sized particles with an aerodynamic diameter 1-2.5 $\mu \mathrm{m}$ in the area with significant technogenic load was $9.8(3.8,12.7) \mu \mathrm{g} / \mathrm{m}^{3}$, i. e. it was 2.7 times higher than on Russkiy Island $\left(3.6(0.5,6.0) \mu \mathrm{g} / \mathrm{m}^{3}\right)(\mathrm{p}=0.003)$.

Air level of coarse particles with an aerodynamic diameter of 2.5-10 $\mu \mathrm{m}$ in Vladivostok was 3.3 times higher $(41.0(21.3,67.4)$ $\mu \mathrm{g} / \mathrm{m}^{3}$ ) compared to the air level of these particles in the area with an insignificant man-made load $\left(12.5(2.3,23.5) \mu \mathrm{g} / \mathrm{m}^{3}\right)$ ( $p=0.00004$ ).

Air concentration of $\mathrm{PM}>10$ with a diameter in the range 10$100 \mu \mathrm{m}$ in Russkiy Island was 1.8 times higher $(17.5(5.1,38.9)$ $\mu \mathrm{g} / \mathrm{m}^{3}$ ) than in the area with significant man-made load (9.9 (0.4, 15.8) $\left.\mu \mathrm{g} / \mathrm{m}^{3}\right)(\mathrm{p}=0.0045)$.

At the same time, air level of $P M>10$ with a diameter in the range $100-2000 \mu \mathrm{m}$ in the area with a high technogenic load was 1.8 times higher than in the favorable zone. The values of air pollution level were $25.8(0,39.2) \mu \mathrm{g} / \mathrm{m}^{3}$ in the unfavorable zone of Vladivostok and $14.5(0,27.2) \mu \mathrm{g} / \mathrm{m}^{3}$ in the area with an insignificant anthropogenic load $(p=0.000008)$.

The comparison of the pollution of atmospheric surface layer in two areas has shown that the mass concentration of PM2.5 and PM10 was 3 times higher in the unfavorable zone of Vladivostok than in its relatively favorable zone - Russkiy Island. In addition, the levels of $P M>10$ also were higher by $10 \%$.

\section{Discussion}

Despite the considerable attention of researchers, the longterm health effects associated with exposure to nano- and micro- sized SPM have not yet been sufficiently studied to talk about safe levels of air pollution. For the first time, using an example of Vladivostok, the authors have evaluated SPM concentration in the atmospheric surface layer taking into account pathophysiological ranges of size distribution, which were selected depending on settling place of SPM in the body, the efficiency of particle elimination, and possible mechanisms of action. The results of the study have shown differences in the concentration of the selected SPM ranges between areas with different anthropogenic stress.

UFP were found only in the air in the area with a significant anthropogenic load. This is due to a permanent source of SPM in the nanoscale range. According to Liang et al. and Pinault et al., the presence of UFP in the air is associated with sources of anthropogenic emissions, namely, internal combustion engines and power plants $[19,20]$. Car exhaust gases contain such products of incomplete combustion of fuel as soot. It consists of carbon particles and have a high capacity for adsorption of heavy hydrocarbons, including benzo(a)pyrene. This property makes soot very dangerous for human health $[12,21]$. Nano-sized particles have physicochemical properties that differ markedly from those of coarse particles [22]. Such unique properties as a very low mass, ultra-high reactivity, the ratio of increased surface area to mass cause more serious adverse effects on human health [23]. Due to a higher adsorption capacity, an increase in the surface area of particles per unit concentration elevates their biological activity exponentially, as well as the possibility for interaction with the cells and a direct biological reaction [24, 25].

One of the possible ways for respiratory absorption of UFP is the deposition on the surface of the olfactory bulb. Nanotoxicological studies have clearly demonstrated that nanoparticles can be deposited in the nasal cavity, with further absorption by the olfactory epithelium and transfer to the brain through the blood-brain barrier. Thus, air pollution can be associated with the risk for human neurodegenerative diseases such as Alzheimer's disease and Parkinson's disease [26].

The presence of fine fraction (PM2.5), namely particles with an aerodynamic diameter of $0.1-1 \mu \mathrm{m}$ and $1-2.5 \mu \mathrm{m}$, in the air in the region with an insignificant anthropogenic load is associated with the use of wood and coal during the heating season. It is consistent with data from other researchers [27]. However, differences in air concentration of particles with an aerodynamic diameter of 0.1-1 $\mu \mathrm{m}$ (an increase by 5 times in the area with a high man-made load) and 1-2.5 $\mathrm{mm}$ (an increase by 2.7 times in the area with a high man-made load) between the sampling sites indicate the contribution of air pollution sources associated with high automobile traffic.

Numerous studies have documented the relationship of the impact of air pollution by PM2.5 with the incidence and mortality of respiratory and cardiovascular diseases [28, 29]. It has been proven that the development and progression of a number of diseases, including asthma, chronic obstructive pulmonary disease, pulmonary fibrosis, lung cancer, type 2 diabetes and obesity, may be associated with PM2.5 exposure. It has been previously demonstrated that the long-term PM2.5 exposure accelerates atherosclerosis and increases blood pressure [4, 16, 30-32].

Particles of coarse fraction (PM10, 2.5-10 $\mu \mathrm{m}$ ) are deposited on the tracheal and bronchial epithelium. The source of particles of this size range in the studied areas of Vladivostok can be both natural processes (soil erosion, biological aerosols, such as mushrooms, bacteria and pollen) and man-made emissions (road 
dust, construction waste, products of oil burning and products of tear and wear of motor vehicles and roads) [33]. Differences in air concentration of these PM (an increase by 3.3 times in the area with a high man-made load) between the studied territories of Vladivostok appear to be associated with a greater man-made load due to the urbanization of the territory.

The predominance of $\mathrm{PM}>10$ particles with an aerodynamic diameter of $10-100 \mu \mathrm{m}$ in the air in Russkiy Island is associated with the formation of dust when motor vehicles are moving along dirt and gravel roads [34]. Air concentration of $P M>10$ particles with an aerodynamic diameter of $100-2000 \mu \mathrm{m}$ was 1.8 times higher in the unfavorable zone of Vladivostok. It may be associated with their high level in road sweepings (pieces of asphalt pavement and car tires appearing as a result of automobile traffic on a defective road surface). Intensive motor traffic causes the aerosolization of these particles and secondary dust formation [35]. Due to gravitational deposition $\mathrm{PM}>10$ stay up in the air only for a short time. After entering the respiratory tract, these particles linger in the nasal cavity and then are excreted from the body.

Thus, our study allowed characterizing the pollution of atmospheric surface layer by micro-sized SPM in two areas of Vladivostok that differ in man-made load.

\section{Conclusion}

For the first time in the Russian Federation, the concentration of SPM in atmospheric surface layer has been established taking into account size distribution of particles characterized by specific pathophysiological effect on the human body. The results indicate differences in the level of SPM fractions, depending on man-made load. The micro-sized particles, which have the most pathogenic effect on the human health, prevail in the air in the area of Vladivostok with a high man-made load. The feature of air pollution in Vladivostok in the area with an insignificant anthropogenic load is the predominance of the coarse fraction of particles with an aerodynamic diameter of more than $10 \mu \mathrm{m}$.

\section{Conflict of Interest}

We declare that we have no conflict of interest.

\section{Ethical approval}

This article does not contain any studies with human participants or animals performed by any of the authors.

\section{References}

1. Global, regional, and national comparative risk assessment of 79 behavioural, environmental and occupational, and metabolic risks or clusters of risks, 1990-2015: a systematic analysis for the Global Burden of Disease Study 2015. Lancet 2016; 388(10053): 1659-1724. https://doi.org/10.1016/50140-6736(16)31679-8.

2. The state of sanitary and epidemiological welfare of population in the Russian Federation in 2015: State report. Moscow, Russia: Federalnaya Sluzhba po Nadzoru v Sfere Zashchity Prav Potrebitelej I Blagopoluchiya Cheloveka, 2016: 200 p. Russian. http://www.rospotrebnadzor.ru/upload/iblock/486/gd 2015 ds.pdf.

3. Golokhvast KS. Atmospheric suspensions in the cities of the Far East of Russia. Vladivostok, Russia: Far Eastern Federal University, 2013; 178 p. Russian.

4. Veremchuk LV, Mineeva EE, Vitkina TI, Gvozdenko TA, Golokhvast KS. Impact of atmospheric microparticles and heavy metals on external respiration function of urbanized territory population. Russ Open Med J 2017; 6(4): e0402. https://doi.org/10.15275/rusomj.2017.0402.

5. Barskova LS, Vitkina TI, Yan'kova VI. The response features of alveolar macrophages to the impact of ambient air particulate matter. Health. Medical ecology. Science 2017; (4): 15-23. Russian. http://doi.org/10.5281/zenodo.835303.

6. Vitkina TI, Veremchuk LV, Simonova I, Gvozdenko TA, Antonyuk MV. Pathogenetic markers of ecologically related respiratory diseases. Bulletin Physiology and Pathology of Respiration 2016; (62): 8-15. Russian. https://doi.org/10.12737/23112.

7. ISO 7708-2006 Air quality. Particle size fraction definitions for healthrelated sampling. Moscow, Russia: Standartinform, 2006; part IV, $10 \mathrm{p}$. Russian. http://docs.cntd.ru/document/1200046160.

8. Yan'kova VI, Vitkina TI, Zyumchenko NE, Barskova LS, Golokhvast KS. The impact of model suspensions of micro-sized suspended particulate matter of atmospheric air on morphological and functional characteristics and parameters of lipid peroxidation of alveolar macrophages of vistar's line rats. Health. Medical ecology. Science 2017; (4): 80-86. Russian. http://doi.org/10.5281/zenodo.835330.

9. Vitkina TI, Yankova VI, Gvozdenko TA, Kuznetsov VL, Krasnikov DV, Nazarenko AV, et al. The impact of multi-walled carbon nanotubes with different amount of metallic impurities on immunometabolic parameters in healthy volunteers. Food Chem Toxicol 2016; 87: 138147. https://doi.org/10.1016/j.fct.2015.11.023.

10. Fang $X$, Fang B, Wang C, Xia T, Bottai M, Fang F, et al. Relationship between fine particulate matter, weather condition and daily nonaccidental mortality in Shanghai, China: A Bayesian approach. PLoS One 2017; 12(11): e0187933. https://doi.org/10.1371/journal.pone.0187933.

11. Rumana HS, Sharma RC, Beniwal V, Sharm AK. A retrospective approach to assess human health risks associated with growing air pollution in urbanized area of Thar Desert, western Rajasthan, India. J Environ Health Sci Eng 2014; 12(1): 23. https://doi.org/10.1186/2052336X-12-23.

12. Noël A, Xiao R, Perveen Z, Zaman HM, Rouse RL, Paulsen DB, et al. Incomplete lung recovery following sub-acute inhalation of combustion-derived ultrafine particles in mice. Part Fibre Toxico 2016; 13: 10. https://doi.org/10.1186/s12989-016-0122-z.

13. Golokhvast K, Vitkina T, Gvozdenko T, Kolosov V, Yankova V, Kondratieva $E$, et al. Impact of atmospheric microparticles on the development of oxidative stress in healthy city/industrial seaport residents. Oxid Med Cell Longev 2015; 2015: 412173. https://doi.org/10.1155/2015/412173.

14. Samoli E, Stafoggia M, Rodopoulou S, Ostro B, Declercq C, Alessandrini $\mathrm{E}$, et al. Associations between fine and coarse particles and mortality in Mediterranean cities: results from the MED-PARTICLES project. Environ Health Perspect 2013; 121(8): 932-938. https://doi.org/10.1289/ehp.1206124.

15. Simoni M, Baldacci S, Maio S, Cerrai S, Sarno G, Viegi G. Adverse effects of outdoor pollution in the elderly. J Thorac Dis 2015; 7(1): 3445. https://doi.org/10.3978/j.issn.2072-1439.2014.12.10.

16. Veremchuk LV, Yankova VI, Vitkina TI, Nazarenko AV, Golokhvast KS. Urban air pollution, climate and its impact on asthma morbidity. Asian Pacific Journal of Tropical Biomedicine 2016; 6(1): 76-79. https://doi.org/10.1016/j.apjtb.2015.10.001.

17. Veremchuk LV, Tsarouhas K, Vitkina TI, Mineeva EE, Gvozdenko TA, Antonyuk MV, et al. Impact evaluation of environmental factors on respiratory function of asthma patients living in urban territory. Environ Pollut 2018; 235: 489-496. https://doi.org/10.1016/j.envpol.2017.12.122.

18. Yankova VI, Gvozdenko TA, Golokhvast KS, Chaika VV, Gorodnyi VA. Granulometric analysis of atmospheric particles from environmentally favorable and problematic areas of Vladivostok. Health. Medical ecology. Science 2014; (2): 62-66. Russian. http://yadi.sk/d/06T4cKshSaP9x. 
19. Liang CS, Duan FK, He KB, Ma YL. Review on recent progress in observations, source identifications and countermeasures of PM2.5. Environ 2016: Int 150-170. https://doi.org/10.1016/j.envint.2015.10.016.

20. Pinault L, Tjepkema M, Crouse DL, Weichenthal S, van Donkelaar A, Martin RV, et al. Risk estimates of mortality attributed to low concentrations of ambient fine particulate matter in the Canadian community health survey cohort. Environ Health 2016; 15: 18. https://doi.org/10.1186/s12940-016-0111-6.

21. Longhin E, Gualtieri M, Capasso L, Bengalli R, Mollerup S, Holme JA, et al. Physico-chemical properties and biological effects of diesel and biomass particles. Environ Pollut 2016; 215: 366-375. https://doi.org/10.1016/j.envpol.2016.05.015.

22. Li N, Georas S, Alexis N, Fritz P, Xia T, Williams MA, et al. A work group report on ultrafine particles (American Academy of Allergy, Asthma \& Immunology): Why ambient ultrafine and engineered nanoparticles should receive special attention for possible adverse health outcomes in humans. J Allergy Clin Immunol 2016; 138(2): 386-396. https://doi.org/10.1016/i.jaci.2016.02.023.

23. Chen R, Hu B, Liu Y, Xu J, Yang G, Xu D, et al. Beyond PM2.5: The role of ultrafine particles on adverse health effects of air pollution. Biochim Biophys Acta 2016; 1860(12): 2844-2855. https://doi.org/10.1016/j.bbagen.2016.03.019.

24. Lee BJ, Kim B, Lee K. Air pollution exposure and cardiovascular disease. Toxicol Res 2014; 30(2): https://doi.org/10.5487/TR.2014.30.2.071.

25. Rinaldo $M$, Andujar $P$, Lacourt A, Martinon L, Canal Raffin $M$, Dumortier $\mathrm{P}$, et al. Perspectives in biological monitoring of inhaled nanosized particles. Ann Occup Hyg 2015; 59(6): 669-680. https://doi.org/10.1093/annhyg/mev015.

26. Costa LG, Cole TB, Coburn J, Chang YC, Dao K, Roque PJ. Neurotoxicity of traffic-related air pollution. Neurotoxicology 2017; 59: 133-139. https://doi.org/10.1016/i.neuro.2015.11.008.

27. Falcon-Rodriguez $\mathrm{Cl}$, Osornio-Vargas AR, Sada-Ovalle I, Segura-Medina P. Aeroparticles, Composition, and Lung Diseases. Front Immunol 2016; 7: 3. https://doi.org/10.3389/fimmu.2016.00003.

28. Hoek G, Krishnan RM, Beelen R, Peters A, Ostro B, Brunekreef B, et al. Long-term air pollution exposure and cardio-respiratory mortality: a review. Environ Health 2013; 12(1): 43. https://doi.org/10.1186/1476069X-12-43.

29. Rodriguez-Villamizar LA, Magico A, Osornio-Vargas A, Rowe BH. The effects of outdoor air pollution on the respiratory health of Canadian children: A systematic review of epidemiological studies. Can Respir J 2015; 22(5): 282-292. https://doi.org/10.1155/2015/263427.

30. Gordon SB, Bruce NG, Grigg J, Hibberd PL, Kurmi OP, Lam KB, et al. Respiratory risks from household air pollution in low and middle income countries. Lancet Respir Med 2014; 2(10): 823-860. https://doi.org/10.1016/S2213-2600(14)70168-7.

31. Raaschou-Nielsen O, Beelen R, Wang M, Hoek G, Andersen ZJ, Hoffmann $B$, et al. Particulate matter air pollution components and risk for lung cancer. Environ Int 2016; 87: 66-73. https://doi.org/10.1016/i.envint.2015.11.007.

32. Kim KH, Kabir E, Kabir S. A review on the human health impact of airborne particulate matter. Environ Int 2015; 74: 136-143. https://doi.org/10.1016/i.envint.2014.10.005

33. Levanchuk AV. Environmental pollution by products of wear and tear automobile-road complex. Gig Sanit 2014; 93(6): 17-21. Russian. https://www.ncbi.nlm.nih.gov/pubmed/25950039.

34. Nikolenko DA, Shul'ga SV, Barikaeva NS. Model of distribution of dust particles in emissions to the atmosphere at construction and operation of motor roads. Internet-vestnik VolgGASU. Seria Stroitel'naa informatika 2014; $\quad$ (12): $7 . \quad$ Russian. https://elibrary.ru/item.asp?id=22701833.

35. Shaikhutdinova AA, Murzabulatov AS. Ecological aspects in the model of municipal passanger traffic organization. Izvestiya Orenburg State
Agrarian University 2013; (1(39)): 210-213. Russian https://elibrary.ru/item.asp?id=18851836.

\section{Authors:}

Lyudmila S. Barskova - Junior Researcher, Laboratory of Medical Ecology and Recreational Resources, Vladivostok Branch of Far Eastern Scientific Centre of Physiology and Pathology of Respiration, Institute of Medical Climatology and Rehabilitative Treatment, Vladivostok, Russia. https://orcid.org/0000-0001-7582-343X.

Tatyana I. Vitkina - DSc, Professor, Head, Laboratory of Medical Ecology and Recreational Resources, Vladivostok Branch of Far Eastern Scientific Centre of Physiology and Pathology of Respiration, Institute of Medical Climatology and Rehabilitative Treatment, Vladivostok, Russia. http://orcid.org/0000-0002-1009-9011.

Tatyana A. Gvozdenko - MD, DSc, Professor, Chief Researcher, Laboratory of Rehabilitation Treatment, Vladivostok Branch of Far Eastern Scientific Centre of Physiology and Pathology of Respiration, Institute of Medical Climatology and Rehabilitative Treatment, Vladivostok, Russia. http://orcid.org/0000-0002-6413-9840.

Lyudmila V. Veremchuk - DSc, Leading Researcher, Laboratory of Medical Ecology and Recreational Resources, Vladivostok Branch of Far Eastern Scientific Centre of Physiology and Pathology of Respiration, Institute of Medical Climatology and Rehabilitative Treatment, Vladivostok, Russia. http://orcid.org/0000-0001-6372-6560.

Kirill S. Golokhvast - MD, DSc, Professor, Senior Researcher, Laboratory of Medical Ecology, Vladivostok Branch of Far Eastern Scientific Centre of Physiology and Pathology of Respiration, Institute of Medical Climatology and Rehabilitative Treatment, Vladivostok, Russia; Deputy Director in Development, Head of the Nano-Centre, Far Eastern Federal University, Vladivostok, Russia. http://orcid.org/0000-0002-4873-2281. 